Journal of Management and Bussines (JOMB)

Volume 1, Nomor2, Desember 2019

p-ISSN : 2656-8918

e-ISSN:2684-8317

DOI : https://doi.org/10.31539/jomb.v1i2.1025

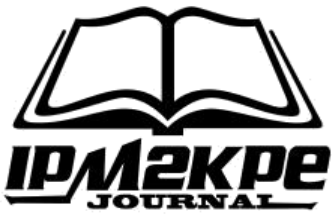

\title{
FAKTOR-FAKTOR YANG MEMPENGARUHI AKUNTABILITAS KINERJA INSTANSI PEMERINTAH DAERAH KABUPATEN OGAN KOMERING ULU
}

\author{
Reni Febrianti ${ }^{1}$, Anis Feblin ${ }^{2}$, Hasiatul Aini ${ }^{3}$ \\ Universitas Baturaja ${ }^{1,2,3}$ \\ feblinfathullah@gmail.com ${ }^{1}$
}

\begin{abstract}
ABSTRAK
Tujuan penelitian ini untuk mengetahui faktor-faktor yang mempengaruhi Akuntabilitas Kinerja Instansi Pemerintah Daerah Kabupaten OKU. Metode yang digunakan dalam penelitian ini adalah non probability sampling yaitu purposive sampling. Teknik analisis yang digunakan adalah regresi linear berganda dan uji hipotesis adalah uji statistik secara parsial (uji t) dan simultan (uji F). Hasil Uji t menunjukkan bahwa ada pengaruh yang signifikan pengendalian intern dan motivasi terhadap Akuntabilitas Kinerja Instansi Pemerintah Daerah Kabupaten OKU dengan nilai t tabel sebesar 2,00758. Hasil uji $\mathrm{F}$ menunjukan nilai sig $0,000<0,05$ ataudiperoleh nilai $\mathrm{F}$ hitung $15,517>\mathrm{F}$ tabel 2,40 yang berarti bahwa secara bersama-sama kejelasan sasaran anggaran (X1), pengendalian akuntansi (X2), sistem pelaporan (X3), pengendalian intern (X4), dan motivasi (X5) berpengaruh signifikan terhadap akuntabilitas kinerja. Berdasarkan koefisien determinasi diperoleh nilai 0,564. Simpulan, kontribusi pengaruh kejelasan sasaran anggaran, pengendalian akuntansi, sistem pelaporan, pengendalian intern, dan motivasi terhadap akuntabilitas kinerja sebesar 56,4\%, sedangkan sisanya $43,6 \%$ dipengaruhi oleh variabel lain yang tidak dijelaskan dalam penelitian ini.
\end{abstract}

Kata Kunci: Akuntabilitas Kinerja, Institusi Pemerintah

\section{ABSTRACT}

The purpose of this study was to determine the factors that influence the Accountability of OKU Regency Government Institution Performance. The method used in this study is non probability sampling, namely purposive sampling. The analysis technique used is multiple linear regression and hypothesis testing is a statistical test partially ( $t$ test) and simultaneous ( $F$ test). T test results show that there is a significant influence of internal control and motivation on the Performance Accountability of $O K U$ Regency Government Agencies with a t table value of 2.00758. F test results show a sig value of $0,000<0.05$ or obtain an $F$ value of 15.517> F table 2.40 which means that together the budget target clarity (X1), accounting control (X2), reporting system (X3), internal control (X4), and motivation (X5) have a significant effect on performance accountability. Based on the coefficient of determination obtained a value of 0.564. Conclusions, the contribution of the clarity of budget targets, accounting controls, reporting systems, internal controls, and motivation to performance accountability was $56.4 \%$, while the remaining $43.6 \%$ was influenced by other variables not explained in this study.

Keywords: Performance Accountability, Government Institutions 


\section{PENDAHULUAN}

Kualitas pelayanan publik dalam suatu daerah menjadi perhatian bersama, peningkatan kualitas pelayanan bagi publik penting dilakukan pemerintah demi tercapainya kepuasan kerja pada masyarakat. Para pejabat publik, unsur-unsur dalam masyarakat sipil dan dunia usaha sama-sama memiliki kepentingan terhadap perbaikan kinerja pelayanan publik. Sebagaimana diketahui, tujuan utama sektor publik adalah pemberian pelayanan publik (public servise) bukan untuk memaksimumkan laba. Tetapi sampai saat ini kita belum tahu bagaimana sesungguhnya pelayanan yang akan diterima rakyat sebagai warga negara dan bagaimana seharusnya pemerintah menyelenggarakan pelayanan publik.

Isu tentang pemberian pelayanan publik semakin mencuat kepermukaan, hal ini tidak dapat dipisahkan dari tingkat keberadaban manusia yang semakin maju. Pemberian pelayanan yang baik oleh lembaga atau instansi pemberi layanan merupakan kata kunci yang menjadi perhatian masyarakat. Akuntansi sektor publik contoh pelayanan dengan perkembangan yang cukup pesat. Perhatian yang lebih besar terhadap praktik akuntansi yang dilakukan oleh lembaga-lembaga pemerintah, perusahaan milik negara atau daerah dan belbagai organisasi publik lainnya dibandingkan dengan masamasa sebelumnya. Tuntutan yang lebih besar dari masyarakat untuk dilakukan transparansi, akuntabilitas dan partisipasi oleh lembaga-lembaga sektor publik, menyebabkan aparatur pemerintah untuk lebih baik dalam mengelola sistem pemerintahan.

Hal ini sesuai dengan Peraturan Presiden Republik Indonesia Nomor 29 Tahun 2014 tentang Sistem Akuntabilitas Kinerja Instansi Pemerintah, setiap Pemerintah Daerah Kabupaten atau Kota menyampaikan Laporan Akuntabilitas Kinerja Instansi Pemerintah (LAKIP) sebagi perwujudan kewajiban suatu instansi pemerintah untuk mempertanggungjawabkan keberhasilan atau kegagalan pelaksanaan misi organisasi dalam mencapai tujuan-tujuan dan sasaran yang telah ditetapkan melalui alat pertanggungjawaban secara periodik setiap akhir anggaran. Media pelaporan akuntabilitas tersebut adalah LAKIP dan SAKIP

Sejalan dengan Instruksi Presiden Nomor 4 Tahun 2011, tentang percepatan peningkatan kualitas akuntabilitas keungan negara, yaitu Badan Pengawas Keuangan dan Pembangunan (BPKP) diberi tugas melakukan asistensi kepada 
kementerian/lembaga/pemerintah daerah untuk meningkatkan pemahaman bagi pejabat pemerintah pusat/daerah dalam pengelolaan keuangan negara, meningkatkan kepatuhan terhadap peraturan perundang-undangan, serta meningkatkan kualitas laporan keuangan dan tata kelola.

Menurut Herawaty (2014) faktor-faktor yang mempengaruhi akuntabilitas kinerja instansi pemerintah adalah: 1) Kejelasan sasaran anggaran, kesesuaian antara pandangan manajemen puncak dengan pandangan manajemen lini bawah. 2) Pengendalian akuntansi, semua prosedur dan sistem formal yang menggunakan informasi untuk menjaga dan mengubah pola aktifitas organisasi, 3) Sistem pelaporan, sistem pelaporan yang baik diperlukan untuk memantau dan mengendalikan kinerja dalam mengimplemtasikan anggaran yang telah ditetapkan. 4)Pengendalian intern, penyusunan dan penyelenggaraan struktur pengendalian intern merupakan tanggung jawab manajemen. 5) Motivasi kekuatan yang mendorong manusia untuk melakukan dalam mencapai tujuan,

Berdasarkan Keputusan Menteri Dalam Negeri No. 690.900-327 Tahun 1996 tentang Pedoman Penilaian Kinerja Keuangan, jika hasil pencapaian antara 90\% - 100\% maka penerimaan Pendapatan Asli Daerah (PAD) dikatakan efektif, dan untuk realisasi belanja jika hasil pencapaian antara 80\% - $90 \%$ maka dikatakan cukup efisien, dan apabila pencapaian 90\%-100\%, maka anggaran belanja dikatakan kurang efisien.

Yang menjadi permasalahan Pemerintah Daerah Kabupaten OKU yaitu realisasi belanja, artinya pemerintah dinilai belum bisa mengefisiensikan dalam menggunakan dana masyarakat agar dapat menghasilkan keluaran yang maksimal. Fenomena di masyarakat yang menggambarkan akuntabilitas keuangan belum berjalan sepenuhnya karena pengukuran kinerja instansi pemerintah lebih menekankan kepada kemampuan Organisasi Perangkat Daerah (OPD) dalam menyerap anggaran. Akuntabilitas keuangan yang dibuat OPD seharusnya bukan hanya sekedar laporan kinerja dan pertanggungjawaban pelaksanaan anggaran yang bersifat formalitas tetapi berisi informasi yang kredibel bagi penggunanya. Maka dari itu pemerintah harus lebih mencermati kejelasan sasaran anggaran instansi pemerintah yang ada di Kabupaten OKU. 
Target target dan realisasi laporan penyelenggaraan pemerintah tidak tercapai, karena belum meratanya pemahaman OPD terhadap indikator yang dinilai dalam Laporan Penyelenggaraan Pemerintah Daerah (LPPD), dan tenaga Sumber Daya Manusia (SDM) yang belum handal dalam penguasaan Informasi Teknologi (IT). Selain itu juga minimnya SDM OPD yang menguasai proses penyusunan laporan kinerja yang sering tidak mengikuti dokumen perencanaan dan standar yang berlaku juga mempengaruhi pencapaian sasaran yang telah ditargetkan pemerintah, hal ini dibuktikan dengan hasil nilai yang diperoleh Kabupaten OKU dalam pembuatan LAKIP dari tahun 2015-2017 masih memperoleh nilai C yang berarti Kabupaten OKU masih bermasalah dengan sistem pelaporan.

Ada lima faktor yang mempengaruhi akuntabilitas kinerja instansi pemerintah, dari ke lima faktor tersebut hanya ada tiga faktor yang bermasalah dalam Laporan Akuntabilitas Kinerja Instansi Pemerintah Daerah Kabupaten OKU, yaitu kejelasan sasaran anggaran, sistem pelaporan dan pengendalian intern. Sedangkan pengendalian akuntansi dan motivasi tidak bermasalah, namun masih ada relevansinya terhadap akuntabilitas kinerja instansi pemerintah, sehingga masih menjadi variabel bebas dalam penelitian ini.

\section{KAJIAN TEORI}

\section{Teori Akuntabilitas}

Akuntabilitas adalah konsep etika yang dekat dengan administrasi publik pemerintahan (lembaga eksekutif pemerintah, lembaga legislatif parlemen dan lembaga yudikatif kehakiman) yang mengandung banyak arti, hal ini sering digunakan secara sinonim dengan konsep-konsep seperti dapat dipertanggungjawabkan (responsibility), kemampuan memberikan jawaban (answeraility), yang dapat dipersalahkan (blameworthiness) dan mempunyai ketidakbebasan (liability).

Akuntabilitas secara umum dapat diartikan sebagai permintaan pertanggungjawaban atas pemenuhan tanggung jawab yang diserahkan kepadanya. Dalam tugasnya mengaudit laporan keuangan, auditor dituntut bekerja dengan akuntabilitas yang tinggi dan secara profesional. Hal ini untuk memenuhi permintaan klien yang menginginkan kinerja yang tinggi. 
Menurut Mardiasmo (2018) pengertian akuntabilitas adalah sebuah kewajiban melaporkan dan bertanggung jawab atas keberhasilan atau pun kegagalan pelaksanaan misi organisasi dalam mencapai hasil yang telah ditetapkan sebelumnya, melalui media pertanggungjawaban yang dikerjakan secara berkala. Akuntabilitas dibagi menjadi dua jenis, yaitu akuntabilitas vertikal, yaitu akuntabilitas pertanggungjawaban yang dilakukan kepada atasan, dan akuntabilitas horizontal, merupakan akuntabilitas pertanggungjawaban yang dilakukan kepada orang atau lembaga setara.

\section{Pengertian Akuntabilitas Kinerja}

Peraturan Presiden Nomor 29 tahun 2014 tentang Sistem akuntabilitas kinerja instansi pemerintah, mendefinisikan akuntabilitas kinerja yaitu perwujudan kewajiban suatu instansi pemerintah untuk mempertanggungjawabkan keberhasilan/kegagalan pelaksanaan program dan kegiatan yang telah diamanatkan para pemangku kepentingan dalam rangka mencapai misi organisasi secara terukur dengan sasaran/target kinerja yang telah ditetapkan melalui laporan kinerja instansi pemerintah yang disusun secara periodik.

Menurut Bastian (2010) akuntabilitas kinerja merupakan salah satu kunci bagi terwujudnya good governance dalam pengelolaan organisasi publik. Jadi tidak ada salahnya jika siklus akuntansi sektor publik diakhiri dengan proses pertanggung jawaban publik. Proses inilah yang menentukan penilaian keberhasilan sebuah organisasi publik dalam mencapai tujuannya.

Menurut Mahsun (2018) lingkungan akuntabilitas mengacu pada kondisi dimana didalamnya akuntabilitas dapat berjalan dengan baik. Ada beberapa persyaratan yang harus dipenuhi untuk menyusun lingkungan akuntabilitas yang baik, antara lain: leadership, recipcoration, equity, trust, transparency, clarity, balance, ownership, consequence, consistency dan follow-up.

\section{Faktor-faktor Mempengaruhi Akuntabilitas Kinerja Instansi Pemerintah}

Menurut Herawaty (2014) faktor-faktor yang mempengaruhi akuntabilitas kinerja instansi pemerintah ada lima, yaitu:

1. Kejelasan Sasaran Anggaran

2. Pengendalian Akuntansi 


\section{Sistem Pelaporan}

4. Pengendalian Intern

5. Motivasi

Dalam penelitian ini tiga faktor yang bermasalah dalam laporan akuntabilitas kinerja instansi pemerintah khususnya Instansi Pemerintah Kabupaten OKU, maka penjelasan tertuju pada tiga faktor tersebut, 1) Kejelasan sasaran anggaran, yaitu sejauh mana tujuan anggaran ditetapkan secara spesifik dengan tujuan agar anggaran tersebut dapat dimengerti oleh orang yang bertanggung jawab atas pencapaian sasaran anggaran tersebut sehingga dapat mendorong karyawan untuk melakukan yang terbaik bagi pencapaian tujuan yang ingin dicapai (Yulianti dkk, 2014). Fungsi anggaran sektor publik antara lain sebagai alat perencanaan, alat pengendalian, alat kebijakan fiskal, alat politik, alat koordinasi dan komunikasi, alat penilaian kinerja, alat motivasi, dan alat menciptakan ruangan publik. (Mahsun \& Heribertus, 2011).

2) Sistem pelaporan, menurut Hidayattullah \& Irene (2015) adalah laporan yang menggambarkan sistem pertanggung jawaban dari bawahan kepada atasan. Sistem pelaporan yang baik diperlukan agar dapat memantau dan mengendalikan kinerja manejerial dalam mengimplementasikan anggaran yang tetah ditetapkan. Menurut Bastian (2010) sistem pelaporan keuangan sektor publik terdiri dari dasar kas (cash base), dasar akrual (accrual base) dan akuntansi dana (fund accounting).

3) Pengendalian intern, Menurut Comitte of the American Institute of Accounntans (1949) pengendalian intern yaitu rencana organisasi dan semua metode serta ketentuan yang terkoordinasi yang dianut perusahaan untuk melindungi harta miliknya, mengecek kecermatan dan keandalan data akuntansi, meningkatkan efisiensi usaha, dan mendorong ditaatinya kebijakan manajemen yang telah ditetapkan. Menurut Bastian (2009) tujuan pengendalian intern adalahuntuk melindungi harta/aktiva organisasi dan pencatatan pembukuannya, mengecek kecermatan dan keandalan data akuntansi, meningkatkkan efisiensi usaha dan mendorong ditaatinya kebijakan manajemen yang telah ditetapkan.

\section{METODE PENELITIAN}

Penelitian ini dilakukan pada organisasi perangkat Daerah Kabupaten OKU. Populasi dalam penelitian ini semua organisasi perangkat Daerah Kabupaten 
OKUberjumlah 47 organisasi, namun dalam pengambilan sampel digunakan teknik non probability sampling yang dengan menggunakan metode purposive sampling, yaitu teknik penentuan sampel dengan pertimbangan tertentu, dan pengambilan sampel berdasarkan kriteria yang ditetapkan peneliti. Kriteria yang harus dipenuhi dalam penelitian ini adalah sebagai berikut: LAKIP disusun oleh Kepala Sub Bagian Keuangan, Kepala Sub Bagian Program dan Perencanaan, dan Bendahara; Kepala Sub Bagian Keuangan dan Kepala Sub Bagian Program dan Perencanaan, memiliki kualifikasi minimal golongan IIId, dan sudah mengikuti Pendidikan dan Pelatihan Kepemimpinan Tingkat 4 (PIM 4); Bendahara, memiliki kualifikasi minimal golongan II, dan sudah mengikuti Pendidikan dan Pelatihan Bendahara; OPD Kabupaten OKU yang bertipe A, yaitu OPD yang memiliki beban kerja besar, wilayah kerja yang luas, memiliki 4 bagian kerja, dikepalai pejabat eselon 2, dan kecamatan dikepalai pejabat eselon 3.

Merujuk pada kriteria yang ditetapkan peneliti, maka penelitian ini hanya membagikan kuesioner kepada Kepala Sub Bagian Keuangan, Kepala Sub Bagian Program dan Perencanaan, dan Bendahara pada Organisasi Perangkat Daerah Kabupaten OKU yang bertipe A yaitu berjumlah 19 OPD, dengan jumlah sampel 57 responden.

\section{HASIL PENELITIAN}

Dalam melakukan rangkaian penelitian ini untuk mendapatkan hasil, peneliti menggunakan perangkat lunak spss versi 21 .

Tabel 1 Hasil Regresi Linear Berganda

\begin{tabular}{llllll}
\hline \multirow{2}{*}{\begin{tabular}{l} 
Model \\
\cline { 3 - 4 } 1
\end{tabular}} & & $\mathrm{~B}$ & Std. Error & $\mathrm{T}$ & Sig. \\
\cline { 3 - 4 } & (Constant) & -2.083 & 2.903 & -.718 & .476 \\
& KejelasanSasaranAnggaran & .130 & .115 & 1.128 & .265 \\
& PengendalianAkuntansi & .010 & .120 & .085 & .932 \\
& SistemPelaporan & -.138 & .166 & -.830 & .410 \\
& PengendalianIntern & .346 & .118 & 2.932 & .005 \\
& Motivasi & .318 & .123 & 2.593 & .012 \\
\hline Sumber: Data primer, 2019 (diolah) & & & &
\end{tabular}

Sumber: Data primer, 2019 (diolah) 
Terlihat pada tabel coefficients hasil persamaan regresi yaitu:

$$
Y=-2,083+0,130 X_{1}+0,010 X_{2}-0,138 X_{3}+0,346 X_{4}+0,318 X_{5}
$$

Interpretasikan sebagai berikut:

1. Angka konstan sebesar -2,083 mempunyai nilai negatif, artinya jika $X_{1}$ (Kejelasan Sasaran Anggaran), $\mathrm{X}_{2}$ (Pengendalian Akuntansi), $\mathrm{X}_{3}$ (Sistem Pelaporan), $\mathrm{X}_{4}$ (Pengendalian Intern), dan $\mathrm{X}_{5}$ (Motivasi) sama dengan nol, maka Y (Akuntabilitas Kinerja) akan turun sebesar 2,083.

2. Angka koefisien regresi $X_{1}$ (Kejelasan Sasaran Anggaran) sebesar 0,130 artinya bahwa jika $\mathrm{X}_{1}$ (Kejelasan Sasaran Anggaran) meningkat satu satuan, maka Y (Akuntabilitas Kinerja) mengalami kenaikan sebesar 0,130 dengan asumsi variabel $\mathrm{X}_{2}$ (Pengendalian Akuntansi), $\mathrm{X}_{3}$ (Sistem Pelaporan), $\mathrm{X}_{4}$ (Pengendalian Intern), dan $\mathrm{X}_{5}$ (Motivasi) tetap.

3. Angka koefisien regresi $X_{2}$ (Pengendalian Akuntansi) sebesar 0,010 artinya bahwa jika $\mathrm{X}_{2}$ (Pengendalian Akuntansi) meningkat satu satuan, maka Y (Akuntabilitas Kinerja) mengalami kenaikan sebesar 0,010 dengan asumsi variabel $\mathrm{X}_{1}$ (Kejelasan Sasaran Anggaran), $X_{3}$ (Sistem Pelaporan), $X_{4}$ (Pengendalian Intern), dan $X_{5}$ (Motivasi) tetap.

4. Angka koefisien regresi $X_{3}$ (Sistem Pelaporan) sebesar -0,138 artinya bahwa jika $X_{3}$ (Sistem Pelaporan) meningkat satu satuan, maka Y (Akuntabilitas Kinerja) mengalami penurunan sebesar 0,138 dengan asumsi variabel $\mathrm{X}_{1}$ (Kejelasan Sasaran Anggaran), $\mathrm{X}_{2}$ (Pengendalian Akuntansi), $\mathrm{X}_{4}$ (Pengendalian Intern), dan $\mathrm{X}_{5}$ (Motivasi) tetap.

5. Angka koefisien regresi $X_{4}$ (Pengendalian Intern) sebesar 0,346 artinya bahwa jika $\mathrm{X}_{4}$ (Pengendalian Intern) meningkat satu satuan, maka Y (Akuntabilitas Kinerja) mengalami kenaikan sebesar 0,346 dengan asumsi variabel $\mathrm{X}_{1}$ (Kejelasan Sasaran Anggaran), $\mathrm{X}_{2}$ (Pengendalian Akuntansi), $\mathrm{X}_{3}$ (Sistem Pelaporan), dan $\mathrm{X}_{5}$ (Motivasi) tetap.

6. Angka koefisien regresi $\mathrm{X}_{5}$ (Motivasi) sebesar 0,318 artinya bahwa jika $\mathrm{X}_{5}$ (Motivasi) meningkat satu satuan, maka Y (Akuntabilitas Kinerja) mengalami kenaikan sebesar 0,318 dengan asumsi variabel $\mathrm{X}_{1}$ (Kejelasan Sasaran Anggaran), $\mathrm{X}_{2}$ (Pengendalian Akuntansi), $\mathrm{X}_{3}$ (Sistem Pelaporan), dan $\mathrm{X}_{4}$ (Pengendalian Intern) tetap. 
Untuk pengujian hipotesis secara parsial terlihat pada tabel 5 coefficients kolom $\mathrm{T}$, dimana besarnya tingkat signifikan $(\alpha)$ yang digunakan adalah $5 \%$ atau 0,05 . Untuk faktor Kejelasan sasaran anggaran (X1), faktor Pengendalian Akuntansi (X2), dan faktor Sistem Pelaporan (X3) terhadap Akuntabilitas Kinerja nilai $(\alpha)$ 0,05 lebih kecil dari nilai sig artinya tidak ada pengaruh yang signifikan terhadap akuntabilitas kinerja instansi Pemerintah Daerah Kabupaten OKU. Sedangkan faktor Pengendalian Intern (X4) dan faktor Motivasi (X5) terhadap Akuntabilitas Kinerja nilai $(\alpha)$ 0,05 lebih besar dari nilai sig artinta ada pengaruh yang signifikan terhadap akuntabilitas kinerja instansi Pemerintah Daerah Kabupaten OKU.

Tabel 2 Hasil Uji F

\begin{tabular}{lllll}
\hline Model & & Df & F & Sig. \\
\hline 1 & Regression & 5 & 15.517 & $.000^{\mathrm{a}}$ \\
& Residual & 51 & & \\
& Total & 56 & & \\
\hline
\end{tabular}

Sumber: Data primer, 2019 (diolah)

Berdasarkan hasil tabel anova nilai sig $0,000<0,05$ dengan nilai $F$ hitung 15, 517 $>\mathrm{F}$ tabel 2,40 maka dapat dikatakan secara simultan ada pengaruh yang signifikan variabel kejelasan sasaran anggaran $\left(\mathrm{X}_{1}\right)$, pengendalian akuntansi $\left(\mathrm{X}_{2}\right)$, sistem pelaporan $\left(\mathrm{X}_{3}\right)$, pengendalian intern $\left(\mathrm{X}_{4}\right)$, dan motivasi $\left(\mathrm{X}_{5}\right)$ terhadap akuntabilitas kinerja instansi Pemerintah Daerah Kabupaten OKU (Y).

Tabel 3 Koefisien Determinasi $\left(\mathrm{R}^{2}\right)$

\begin{tabular}{llll}
\hline Model & $\mathrm{R}$ & R Square & Adjusted R Square \\
\hline 1 & $.777^{\mathrm{a}}$ & .603 & .564 \\
\hline \multicolumn{4}{c}{ Sumber: } \\
Data & primer, 2019 (diolah)
\end{tabular}

Hasil koefisien determinasi di lihat pada nilai adjusted $R$ square sebesar 0,564 atau 56,4\%. Hal ini menunjukkan bahwa kontribusi pengaruh $\mathrm{X}_{1}$ (kejelasan sasaran anggaran), $\mathrm{X}_{2}$ (pengendalian akuntansi), $\mathrm{X}_{3}$ (sistem pelaporan), $\mathrm{X}_{4}$ (pengendalian intern) dan $\mathrm{X}_{5}$ (motivasi) terhadap $\mathrm{Y}$ (Akuntabilitas Kinerja) Instansi Pemerintah Daerah Kabupaten OKU sebesar 56,4\%, sisanya 43,6\% dipengaruhi oleh variabel sumber daya manusia dan komitmen organisasi. 


\section{PEMBAHASAN}

Penelitian ini dilakukan untuk mengetahui faktor-faktor apa sajakah yang mempengaruhi akuntabilitas kinerja instansi Pemerintah Daerah Kabupaten OKU.Berdasarkan hasil analisis data bahwa tidak ada pengaruh yang signifikan kejelasan sasaran anggaran $\left(\mathrm{X}_{1}\right)$ terhadap akuntabilitas kinerja instansi Pemerintah Daerah Kabupaten OKU. Hal ini disebabkan karena sasaran anggaran Pemerintah Daerah Kabupaten OKU lebih menekankan kepada kemampuan OPD dalam menyerap anggaran, namun belum bisa mengefisiensikan penggunaan dana anggaran yang dibelanjakan untuk kepentingan masyarakat, sehingga belum menghasilkan keluaran yang maksimal.

Hasil penelitian ini sesuai dengan teori yang dikemukakan oleh Mahsun (2018) bahwa kejelasan sasaran anggaran juga merupakan salah satu elemen penopang akuntabilitas. Agar individu atau grup melaksanakan wewenang dan memenuhi tanggung jawab, mereka perlu gambaran yang jelas mengenai apa saja yang mereka akan laksanakan dan hasil apa yang diharapkan. Mencoba mengendalikan orang atau grup untuk hasil yang mereka tidak mengetahui ekspektasinya akan menjadi sesuatu yang sulit atau tidak dapat dicapai.

Hasil analisis data juga menunjukkan bahwa tidak ada pengaruh yang signifikan pengendalian akuntansi $\left(\mathrm{X}_{2}\right)$ terhadap akuntabilitas kinerja instasi Pemerintah Daerah Kabupaten OKU, ini disebabkan karena tanggung jawab kinerja tidak selamanya ada hubungan dengan pengendalian akuntansi. Karena pengendalian akuntansi meliputi rencana organisasi dan semua metode yang berkaitan dengan data akuntansi, dan berhubungan langsung dengan pengamanan harta kekayaan dan keandalan catatan keuangan. Didalam LAKIP pengendalian akuntansi hanya sebagai proses pelaporan bukan faktor utama dalam tanggung jawab kinerja instansi pemerintah Daerah Kabupaten OKU.

Hasil penelitian ini sesuai dengan Peraturan Presiden Republik Indonesia Nomor 29 Tahun 2014 tentang Sistem Akuntabilitas Kinerja Instansi Pemerintah (SAKIP), media pelaporan akuntabilitas adalah Laporan Akuntabilitas Kinerja Instansi Pemerintah (LAKIP), dalam pasal 5 disebutkan bahwa penyelenggaraan SAKIP meliputi: a. rencana strategis; b. perjanjian kinerja; c. pengukuran kinerja; d. pengelolaan data kinerja; e. pelaporan kinerja; dan f. review dan evaluasi kinerja. 
Demikian juga dengan variabel sistem pelaporan, dimana hasil analisis data menunjukkan bahwa tidak ada pengaruh yang signifikan sistem pelaporan $\left(\mathrm{X}_{3}\right)$ terhadap akuntabilitas kinerja instasi Pemerintah Daerah Kabupaten OKU. Hal ini disebabkan karena masih minimnya SDM OPD Kabupaten OKU yang menguasai proses penyusunan laporan kinerja yang sering tidak mengikuti dokumen perencanaan dan standar yang berlaku, sehingga mempengaruhi pencapaian sasaran yang telah ditargetkan.

Hasil penelitian ini juga sesuai dengan teori yang dikemukakan oleh Mahsun (2018) bahwa dalam mengimplementasikan akuntabilitas pada umumnya menemui kendala yang justru bisa menjadi counter-productive dalam menciptakan kesehatan dan hubungan akuntabilitas yang efektif, salah satunya adalah kekurangan sumber daya.

Namun lain halnya dengan variabel pengendalian intern, dimana hasil analisis data menunjukkan bahwa ada pengaruh yang signifikan pengendalian intern $\left(\mathrm{X}_{4}\right)$ terhadap akuntabilitas kinerja instasi Pemerintah Daerah Kabupaten OKU. Hasil penelitian ini sesuai dengan teori yang dikemukakan oleh Bastian (2009) bahwa pengendalian dapat diinterpretasikan sebagai proses maupun pengarah. Sebagai proses, pengendalian lebih sebagai alat manajemen dalam proses pelaksanakan keputusan. Berarti pengendalian telah melekat pada manajemen organisasi yang terkait. Pengendalian akan memberikan visi jangka panjang dari berbagi tuntutan keputusan, sehingga pengendalian dapat dikatakan sebagai salah satu aspek penentu keberhasilan manajemen dalam melaporkan pertanggung jawaban (akuntabilitas).

Demikian juga dengan variabel motivasi, hasil analisis data menunjukkan bahwa ada pengaruh yang signifikan motivasi $\left(\mathrm{X}_{5}\right)$ terhadap akuntabilitas kinerja instansi Pemerintah Daerah Kabupaten OKU. Hal ini sesuai dengan teori yang dikemukakan oleh Robbins dan Timothy (2012) bahwa motivasi kerja mendorong pegawai untuk bekerja dengan baik.

Secara simultan ada pengaruh yang signifikan kejelasan sasaran anggaran, pengendalian akuntansi, sistem pelaporan, pengendalian intern, dan motivasi terhadap akuntabilitas kinerja, hal ini berarti adanya kejelasan sasaran anggaran, pengendalian akuntansi, sistem pelaporan, pengendalian intern, dan motivasi akan berpengaruh terhadap akuntabilitas kinerja, sebaliknya semakin tidak adanya kejelasan sasaran 
anggaran, pengendalian akuntansi, sistem pelaporan, pengendalian intern, dan motivasi maka akuntabilitas kinerja akan semakin menurun.

Hasil penelitian ini didukung dengan penelitian sebelumnya seperti yang dilakukan oleh Herawaty (2014) melakukan penelitian tentang "Faktor-faktor yang Mempengaruhi Akuntabilitas Kinerja Instansi Pemerintah Daerah Kota Jambi”. Teknik analisis yang digunakan adalah regresi linear berganda. Hasil penelitian diperoleh simpulan bahwa secara parsial hanya variabel motivasi yang memiliki pengaruh siginifikan terhadap akuntabilitas kinerja. Secara simultan variabel kejelasan sasaran anggaran, pengendalian akuntansi, sistem pelaporan, pengendalian intern, dan motivasi memiliki pengaruh terhadap akuntabilitas kinerja.

Hasil penelitian ini didukung juga dengan penelitian sebelumnya yang dilakukan oleh Perwirasari (2016) melakukan penelitian tentang "Faktor-faktor yang Mempengaruhi Akuntabilitas Kinerja Instansi Pemerintah (AKIP)". Metode penelitian ini menggunakan teknik analisis regresi linear berganda. Hasil penelitian ini menunjukkan bahwa pemahaman prinsip-prinsip good governance (GG), pengendalian intern (SPI), gaya kepemimpinan (GYK) dan ketaatan pada peraturan perundangundangan (KPP) berpengaruh positif signifikan terhadap akuntabilitas kinerja instansi pemerintah (AKIP) baik secara parsial maupun simultan.

\section{SIMPULAN}

Berdasarkan pembahasan yang telah diuraikan serta hasil analisis yang dilakukan peneliti maka dapat diambil kesimpulan bahwa faktor-faktor yang menjadi variabel penelitian secara bersama-sama (simultan) memiliki pengaruh yang signifikan terhadap akuntabilitas kinerja. Kontribusi pengaruh yang diberikan sebesar 56,4\% dalam penelitian ini, karena faktor sumber daya manusia dan komitmen organisasi sebesar 43,6\% tidak bisa ditinggalkan untuk suatu akuntabilitas dalam suatu organisasi.

\section{DAFTAR PUSTAKA}

Bastian, B., Indra, I. (2009). Akuntansi Sektor Publik di Indonesia. BPFE: Yogyakarta . (2010). Akuntansi Sektor Publik Suatu Pengantar Edisi ketiga. Jakarta: Erlangga

Herawaty, N. (2014). Faktor-Faktor yang Mempengaruhi Akuntabilitas Kinerja Instansi Pemerintah. Jurnal Cakrawala Akuntansi, 6(2), 151-161

Hidayattullah, A., Irene, I. (2015). Pengaruh Kejelasan Sasaran Anggaran, Pengendalian Akuntansi, Sistem Pelaporan terhadap Akuntabilitas Kinerja SKPD di Merauke. 
Prosiding Seminar Nasional Multi Disipilin Ilmu \& Call For Papers Unisbank (Sendi_U)

Instruksi Presiden Nomor 4. (2011). Percepatan Peningkatan Kualitas Akuntabilitas Keuangan Negara

Keputusan Dalam Negeri Nomor 690.900-327 Tahun 1996 tentang Pedoman Penilaian Kinerja Keuangan

Mahsun, M., Heribertus, H. (2011). Akuntansi Sektor Publik Edisi ketiga. BPFE: Yogyakarta

Mahsun, M., Muhamad, M. (2018). Pengukuran Kinerja Sektor Publik Edisi Pertama. BPFE: Yogyakarta

Mardiasmo, M. (2018). Akuntansi Sektor Publik. Andi: Yogyakarta

Peraturan Presiden Nomor 29 Tahun 2014 tentang Sistem Akuntabilitas Kinerja Instansi Pemerintah

Perwirasari, F. B. P., Subowo, S. (2016). Faktor-faktor yang Mempengaruhi Akuntabilitas Kinerja Instansi Pemerintah (AKIP). Skripsi. Fakultas Ekonomi Universitas Negeri Semarang (Terpublikasi)

Robbins, S. P., Timothy A. J. (2012). Perilaku Organisasi (Organizational Behavior). Edisi Kedua belas. Buku 1. Buku2. Jakarta: Salemba Empat

Yulianti, R., Hardi, H., \& Rusli, R. (2014). Pengaruh Kejelasan Sasaran Anggaran, Kesulitan Sasaran Anggaran, Pengendalian Akuntansi dan Sistem Pelaporan terhadap Akuntabilitas Kinerja Instansi Pemerintah Studi pada Satuan Kerja Perangkat Daerah Kabupaten Pelalawan.JOM (Jurnal Online Mahasiswa) Fakultas Ekonomi,1(2), 1-15 